\title{
Effect of ionophores and 2-bromoethanesulphonic acid in hen caecal methanogenic cultures
}

\author{
M. Marounek', V. $\operatorname{Rada}^{2}$ and V. Benda ${ }^{3}$ \\ 'Institute of Animal Physiology and Genetics, Czech Academy of Sciences \\ 10400 Prague 10 - Czech Republic \\ ${ }^{2}$ Department of Microbiology and Biotechnology, Czech Agricultural University in Prague \\ 16500 Prague 6 - Suchdol, Czech Republic \\ ${ }^{3}$ Department of Biochemistry and Microbiology. Institute of Chemical Technology \\ 16628 Prague 6 - Dejvice, Czech Republic
}

(Received 31 July 1996; accepted 13 September 1996)

\begin{abstract}
Laying hens, one year of age, fed a commercial concentrate were killed, and their caecal contents inoculated into a nutrient broth with starch as the energy source. Cultures were incubated for $24 \mathrm{~h}$ and production of methane, hydrogen and volatile fatty acids (VFA) measured. Thirteen mols of VFA were produced per 1 mol of methane in controf incubations. Acetate, propionate and butyrate accounted for $89-94 \%$ of metabolite carbon. Only traces of lactate were produced. Monensin and salinomycin at $5 \mathrm{mg} / \mathrm{l}$ significantly decreased production of methane, total VFA, acetate, butyrate and valerate. Similar fermentation shifts were found in cultures containing 2-bromoethanesulphonic acid (2-BES) at $10 \mathrm{mmol} / 1$. Propionate percentages were increased in all treated cultures. Hydrogen recoveries were incomplete in control cultures (70.5-82.1\%). The headspace gas of control cultures contained ca $1 \%(\mathrm{v} / \mathrm{v})$ of molecular hydrogen. Approximately twice more hydrogen gas accumulated in treated cultures.
\end{abstract}

KEY WORDS: hens, caeca, fermentation, methane

\section{INTRODUCTION}

Poultry caeca are colonized by an abundant bacterial flora. Most of the organisms present are obligate anaerobes (Rada et al., 1995). An integral part of the anaerobic microflora in fermentive sections of animal digestive tract are 
methanogens. Methanogens maintain concentration of hydrogen in anaerobic habitats low, enabling the enzymatic oxidation of NADH formed during glycolysis. Alternative ways of $\mathrm{H}_{2}$ utilization are the synthesis of acetate from $\mathrm{CO}_{2}$ and $\mathrm{H}_{2}$, reduction of sulphates, nitrates and hydrogenation of unsaturated fatty acids. Poultry caecal methanogens have not been described in available literature, although there is evidence for their existence (Barrow, 1992). Nothing is known about acetogenic bacteria in poultry caeca, and in general, poultry caecal metabolism has not at present been clearly understood. In preliminary experiments, we did not detect production of methane in young chickens, but we found a significant methanogenesis in caeca of laying hens. The principal substrates of caecal microorganisms are plant polysaccharides. Starch is an important substrate for caecal microorganisms, in spite of the fact that most of starch is digested before the caeca. Abundant starch granules can be easily recognized in the poultry caecal contents, microscopically, after the iodine staining. Both ionophores and 2-BES alter fermentation stoichiometry in fermentive sections of the animal digestive tract. The latter compound is a methyl-coenzyme $M$ reductase inhibitor. Recent papers describe its action in the rumen and hindgut of cattle (De Graeve et al., 1991), in the hindgut of pigs (De Graeve et al., 1994) and in the human colon (Bernalier et al., 1993). Ionophores alter fermentation pattern in a different way. Their mode of action is based on inhibition of gram-positive bacteria and those bacteria which strain gram-negatively, but have a gram-positive structure of the cell wall (Nagaraja and Taylor, 1987). There are reports on effect of ionophores on caecal fermentation in cattle (Marounek et al., 1990) and in rabbits (Marounek et al., 1995).

The aim of this study was to determine the composition of fermentation end-products in cultures of poultry caecal microorganisms growing on starch, and to assess their susceptibility to ionophores and 2-bromoethanesulphonic acid (2-BES).

\section{MATERIAL AND METHODS}

Nine laying hens (Dominant D-102 breed), one year of age, were fed a commercial concentrate without antimicrobials. Concentrate contained wheat $(40 \%)$, maize ( $26 \%)$, soyabean meal $(20 \%)$, mineral supplement $(9.5 \%)$, protein supplement $(4 \%)$ and a vitamin supplement $(0.5 \%)$. Three hens per experiment were used. Hens were killed by cervical dislocation, caecal contents pooled and immediately suspended in sterile VL broth (Barnes and Impey, 1971) with starch as the energy source. The VL broth contained (in grams per litre): trypton -10 , yeast extract -5 , meat extract $-2, \mathrm{NaHCO}_{3}-10, \mathrm{NaCl}-5$, soluble starch -6 , 
cysteine hydrochloride -0.5 . Ten grams of the caecal contents were suspended in $100 \mathrm{ml}$ of the broth. To provide the anaerobiosis, the $\mathrm{CO}_{2}$ atmosphere was used. The same broth was used to culture caecal microorganisms. Sterile broth $(100 \mathrm{ml})$ in $300 \mathrm{ml}$ bottles, hermetically closed by rubber stoppers, was inoculated by adding $5 \mathrm{ml}$ of the diluted caecal contents and incubated at $39^{\circ} \mathrm{C}$ for $24 \mathrm{~h}$.

In the first experiment, effects of monensin (Elanco, USA.) at 0 and $5 \mathrm{mg} / \mathrm{l}$ were investigated. Effects of salinomycin (Hoechst, Germany) were studied in the second experiment, using the same concentration of the ionophore. The third experiment was carricd out to specify effect of Na-salt of 2-BES (Fluka, Switzerland) at 0 and $10 \mathrm{mmol} / \mathrm{l}$. All control or experimental arrangements were incubated in four replicates. Volatile fatty acids (VFA) in the culture fluid were estimated by titration, after steam distillation. Their molar composition was determined by gas chromatography, using a $2.4 \mathrm{~m}$ column of Supelcoport with $5 \%$ FFAP (Supelco, USA) and a flame-ionization detector. The separation was carried out at $140^{\circ} \mathrm{C}$ and at an inlet $\mathrm{N}_{2}$ pressure of $80 \mathrm{kPa}$. Lactate was oxidized to acetaldehyde and measured by means of microdiffusion units (Conway, 1957). Samples of the headspace gas were taken at the end of the incubation by means of a gas-tight syringe and analysed using the same chromatographic equipment. At the same time, the manometric pressure in incubation vessels was measured. Methane production was calculated as the product of methane concentration in the gas phase and total gas production. Molecular $\mathrm{H}_{2}$ was determined on a Carbosieve S column (Supelco, USA.), with a thermal conductivity detector. The separation was carried out at $170^{\circ} \mathrm{C}$. The carrier gas was argon. Metabolic hydrogen balance was computed according to Demeyer and Van Nevel (1975). The results summarized in tables are related to a difference between the beginning and the end of the incubation. Initial concentrations of VFA in cultures were low, ca $1 \mathrm{mmol} / \mathrm{l}$.

The significance of differences was evaluated by the t-test.

\section{RESULTS}

Caecal microorganisms converted substrate carbon into VFA and methane (Table 1, 2). Acetate, propionate and butyrate accounted for $89.4-94.3 \%$ of the metabolite carbon. Only traces of lactate $(<0.4 \mathrm{mmol} / 1)$ were formed. Both monensin and salinomycin significantly $(\mathrm{P}<0.05)$ decreased production of methane, total VFA, acetate, butyrate and valerate (Table 1). Similar fermentation shifts were found in cultures of caecal microorganisms supplied with 2-BES (Table 2). This compound, however, inhibited methanogenesis more efficiently. Propionate production was stimulated $(\mathrm{P}<0.05)$ in cultures with salinomycin. Propionate percentages increased in all treated cultures. Thirteen 
TABLE 1

Effect of monensin and salinomycin on production of methane, hydrogen and volatile fatty acids in cultures of caecal microorganisms of hens

\begin{tabular}{lccccc}
\hline Metabolite & \multicolumn{2}{c}{ Monensin, mg/l } & & \multicolumn{2}{c}{ Salinomycin, $\mathrm{mg} / \mathrm{l}$} \\
\cline { 2 - 3 } \cline { 5 - 6 } mmol/flask & \multicolumn{2}{c}{0} & 5 & 0 & 5 \\
\hline Methane & $0.82 \pm 0.08$ & $0.40 \pm 0.04^{*}$ & & $0.96 \pm 0.08$ & $0.30 \pm 0.07^{*}$ \\
Hydrogen & $0.08 \pm 0.08$ & $0.23 \pm 0.03^{*}$ & & $0.12 \pm 0.11$ & $0.24 \pm 0.06$ \\
Acetate & $4.84 \pm 0.23$ & $3.40 \pm 0.20^{*}$ & & $5.35 \pm 0.08$ & $4.02 \pm 0.21^{*}$ \\
Propionate & $4.54 \pm 0.23$ & $4.54 \pm 0.29$ & & $3.50 \pm 0.08$ & $4.48 \pm 0.21^{*}$ \\
Butyrate & $2.35 \pm 0.21$ & $1.22 \pm 0.09^{*}$ & & $2.56 \pm 0.05$ & $0.99 \pm 0.07^{*}$ \\
Valcrate & $0.42 \pm 0.06$ & $0.09 \pm 0.01^{*}$ & & $0.08 \pm 0.03$ & $0.08 \pm 0.01^{*}$ \\
Total VIFA & $12.15 \pm 0.47$ & $9.25 \pm 0.51^{*}$ & & $11.96 \pm 0.26$ & $9.57 \pm 0.39^{*}$ \\
2H recovery, \% & $76.0 \pm 1.6$ & $84.5 \pm 2.5^{*}$ & & $70.5 \pm 1.6$ & $77.4 \pm 3.5^{*}$ \\
\hline
\end{tabular}

substrate: starch $(6 \mathrm{~g} / 1)$. Mean values with standard deviations

* significantly $(\mathrm{P}<0.05)$ different from the control

mols of VFA were produced per $1 \mathrm{~mol}$ of methane in control cultures, on averagc. The headspace gas of control cultures contained $0.7-1.3 \%(\mathrm{v} / \mathrm{v})$ of molecular hydrogen. Both ionophores and 2-BES increased accumulation of hydrogen gas. Average hydrogen recoveries in control cultures were 76.0, 70.5 and $82.1 \%$, in the first, second and the third experiment, respectively. Recoveries of hydrogen were significantly increased in cultures with ionophores, but not in those containing 2-BES.

TABLF 2

Effect of 2-bromocthanesulphonic acid on production of methanc, hydrogen and volatile fatty acids in cultures of caecal microorganisms of hens

\begin{tabular}{lcc}
\hline Metabolite & \multicolumn{2}{c}{ 2-BES, mmol/1 } \\
\cline { 2 - 3 } mmol/flask & 0 & 10 \\
\hline Methane & $0.77 \pm 0.08$ & $0.01 \pm 0.01^{*}$ \\
Hydrogen & $0.18 \pm 0.13$ & $0.40 \pm 0.10^{*}$ \\
Acetate & $3.10 \pm 0.09$ & $2.29 \pm 0.04^{*}$ \\
Propionate & $3.32 \pm 0.09$ & $3.35 \pm 0.10$ \\
Butyrate & $2.17 \pm 0.07$ & $1.82 \pm 0.06^{*}$ \\
Valerate & $0.34 \pm 0.02$ & $0.25 \pm 0.01^{*}$ \\
Total VFA & $8.93 \pm 0.25$ & $7.71 \pm 0.18^{*}$ \\
2H recovery, \% & $82.1 \pm 1.8$ & $76.3 \pm 1.6^{*}$ \\
\hline
\end{tabular}

substrate: starch $(6 \mathrm{~g} /)$. Mean values with standard deviations

* significantly $(P<0.05)$ different from the control 


\section{DISCUSSION}

Contrary to herbivorous mammals, the digestive function of the poultry caeca is open to question, primarily due to their small volume (ca $0.5 \%$ of the body weight, $\mathrm{v} / \mathrm{w}$ ). Among the functions suggested for poultry caeca are the following: absorption of water and non-protein nitrogen, digestion of starch, cellulose and protein, synthesis of vitamins and self-vaccination (Mattocks, 1971). It is nevertheless interesting to compare caecal metabolic pattern and susceptibility to methane inhibitors in different animal species. Reports on effect of ionophores on hindgut fermentation in farm animals are scarce. Marounek et al. (1990) found that monensin increased the molar percentage of propionate and decreased molar percentage of butyrate and production of methane in cultures of the caecal and colonic contents of cattle. Acetate was not influenced. On the other hand, ionophores (monensin, salinomycin and maduramicin) stimulated methanogenesis in the caecal contents of rabbits (Marounek et al., 1995), probably due to their inhibitory action on alternative ways of hydrogen utilization. In the hindgut of cattle, the addition of 2-BES increased VFA production, mainly due to an increase in acetate formation (De Graeve et al., 1991). Also in the large intestine of pigs, 2-BES stimulated acetogenesis (De Graeve et al., 1994).

In this study, effects of ionophores and 2-BES on poultry caecal fermentation in vitro were similar. Both additives decreased methanogenesis and produced similar fermentation shifts, in spite of the fact, that their modes of action differ. Whereas 2-BES inhibits methanogenesis directly, ionophores inhibit hydrogenproducing bacteria and thus decrease the amount of substrate available for methanogens. The molar ratio of VFA to methane found in this study was distinctly higher than that observed in the rumen (Baldwin et al., 1970), which is a typical methanogenic habilat. Hydrogen recovery values in hen caecal cultures were intermediate to those found in incubations of the sheep rumen and pig caecal contents (Demeyer at al., 1989). Low $2 \mathrm{H}$ recoveries are usually associated with $\mathrm{H}_{2}$-dependent acetogenesis. Although it is probable that a certain acctogenesis in the caeca of laying hens exists (judging from incomplete hydrogen recovery values), its real importance in poultry caeca remains to be determined.

\section{$\Lambda$ CKNOWLEDGEMENTS}

This study was supported by grant No. 524/96/0543 of the Grant Agency of the Czech Republic. 


\section{REFERENCES}

Baldwin R.L., Lucas H.L., Cabrera R., 1970. Fnergetic relationships in the formation and utilization of fermentation end-products. In: A.T. Phillipson (Editor). Physiology of digestion and metabolism in the ruminants. Oriel Press, Newcastle upon Tyne, pp. 319-334

Barnes E.M., Impey C.S., 1971. The isolation of the anacrobic bacteria from the chicken caeca with particular reference to members of the family Bacteroidaceae. In: D.A. Shapton, R.G. Beard (Editors). Isolation of anaerobes. S.A.B. Technical Series No.5. Academic Press, London

Barrow P.A., 1992. Probiotics for chickens. In: R. Fuller (Editor). Probiotics. Chapman and Hall, University Press, Cambridge, pp. 225-257

Bernalier A., Doisneau E., Cordelet C., Beaumatin P., Durand M., Grivet J.P., 1993. Competition for hydrogen between methanogenesis and hydrogenotrophic acetogenesis in human colonic flora studied by ${ }^{13} \mathrm{C}$ NMR. Proc. Nutr. Soc. 52, $118 \mathrm{~A}$

Conway E.J., 1957. Microdiffusion Analysis and Volumetric Error 4th ed. Crosby Lockwood and Son, London, pp. 277-278

De Graeve K.G., Grivet J.P., Durand M., Beaumatin P., Cordelet C., Hannequart G., Demeyer D., 1994. Competition between reductive acetogenesis and methanogenesis in the pig largeintestinal Rora. J. Appl. Bacteriol. 76, 55-61

De Graeve K.G., Grivet J.P., Durand M., Demeyer D., 1991: Effect of 2-bromoethanesulfonic acid, a methanogen inhibitor, on fermentation in the rumen and hindgut. Reprod. Nutr. Devclop. 31, 324

Demeyer D., De Graeve K., Durand M., Stevani J., 1989. Acetate: a hydrogen sink in hindgut fermentation as opposed to rumen fermentation. Acta Vet. Scand. 86, Suppl., 68-75

Demeyer D.I., Van Nevel C.J., 1975. Methanogenesis, an integrated part of carbohydrate fermentation, and its control. In: I.W. MeDonald, A.C.I. Warner (Editors). Digestion and metabolism in the ruminant. The University of New England Publishing Unit, Armidale, Australia, pp. 366-382

Marounek M., Petr O., Machañová L., 1990. Effect of monensin on in vitro fermentation of maize starch by hindgut contents of cattle. J. Agric. Sci., Camb. 115, 389-392

Marounek M., Skrivanova V., Savka O.G., 1995. Effect of antimicrobial fecd additives on rabbit caccal methanogenesis in vitro. Ann. Zootech. 44, Suppl., 158

Mattocks J.G.M., 1971. Some aspects of the problem of cellulose digestion and caecal function in the domestic goose. MSc thesis. The Bath University of Technology

Nagaraja T.G., Taylor M.B., 1987. Susceptibitity and resistance of ruminal bacteria to antimicrobial feed additives. Appl. Fnviron. Microbiol. 53, 1620-1625

Rada V., Marounek M., Rychlý I., Šantrůčkova D., Vořišek K.,1995. Effect of Lactobacillus salivarius administration on microflora in the crop and caeca of broilcr chickens. J. Anim. Feed Sci. 4, 161-170

\section{STRESZCZENIE}

Wpływ jonoforów i kwasu 2-bromoetanosulfonowego na aktywność metaboliczną metanogennych drobnoustrojów jelita cienkiego u kur

Jednoroczne kury nioski żywione mieszanką przemystową ubijano i treścią jelita cienkiego inokulowano pożywką bulionową, zawicrającą skrobię jako źródło energii. Kultury inkubowano przez 24 godz. i oznaczano produkcję metanu, wodoru i lotnych kwasów tluszzzowych (VFA). 
W inkubacji kontrolnej na 1 mol metanu wytwarzane było 13 moli VFA. Octany, propionany i maślany stanowiły 89-94\% metabolitów węgla. Powstawały tylko śladowe ilości mleczanów.

Monensin i salinomycyna w ilości $5 \mathrm{mg} / 1$ istotnie obniżały produkcję metanu, sumę VFA, octanów, maślanów i walerianianów. Podobny przebieg fermentacji stwierdzono w kulturach zawierających kwas 2-bromoetanosulfonowy (2-BES) w ilości $10 \mathrm{mmol} / \mathrm{l}$. Procentowy udział propionanów zwiększał się we wszystkich roztworach inkubowanych kultur. W kulturach kontrolnych odzyskanie wodoru wynosiło od 70,5 do $82,1 \%$. Wydzielony gaz podczas inkubacji kultur kontrolnych zawierał około $1 \%(\mathrm{v} / \mathrm{v})$ molekularnego wodoru. Około dwa razy tyle gazowego wodoru gromadziło się w kulturach doświadczalnych. 